\title{
Fungal infections of the central nervous system: The clinical syndromes
}

\author{
J. M. K. Murthy \\ Department of Neurology, The Institute of Neurological Sciences, CARE Hospital, Hyderabad, India
}

\begin{abstract}
Fungal infections of the central nervous system (CNS) are being increasingly diagnosed both in immunocompromised and immunocompetent individuals. Sinocranial aspergillosis is more frequently described from countries with temperate climates, more often in otherwise immunocompetent individuals. The clinical syndromes with which fungal infections of the CNS can present are protean and can involve most part of the neuroaxis. Certain clinical syndromes are specific for certain fungal infections. The rhinocerebral form is the most common presenting syndrome with zygomycosis and skull-base syndromes are often the presenting clinical syndromes in patients with sinocranial aspergillosis. Subacute and chronic meningitis in patients with HIV infection is more likely to be due to cryptococcal infection. Early recognition of the clinical syndromes in an appropriate clinical setting is the first step towards achieving total cure in some of these infections.
\end{abstract}

Key words: Clinical syndromes, fungal infections, rhinocerebral syndromes, sinocranial aspergillosis, skullbase syndromes

Fungal infections of the central nervous system (CNS) are being increasingly diagnosed. Two main factors contribute to this steady increase of fungal infections, namely the widespread use of antibacterial agents and a rapid increase in the numbers of the immunocompromised population. ${ }^{[1,2]}$ Modern therapeutic modalities such as cancer chemotherapy and organ transplantation have greatly increased the immunocompromised population who are at a risk of invasive fungal infections. ${ }^{[1,3]}$ Fungal infections of the CNS account for a significant proportion of opportunistic infections in patients with HIV. ${ }^{[4]}$

Most of the fungi are aerosolized and inhaled and initiate a primary pulmonary infection which is usually self-limited. Hematogenous dissemination may follow the initial infection, with subsequent involvement of the CNS. Local extension from paranasal sinuses, ear and orbit ${ }^{[5]}$ and rarely trauma ${ }^{[6]}$ also provide the route to intracranial spread. The hyphae or molds (species of Aspergillus, Rhizopus) generally cause focal disease with hemorrhagic necrosis secondary to vascular thrombosis. The yeasts (species of Cryptococcus) tend to cause a more diffuse process with the base of the brain being primarily affected.

The clinical syndromes with which CNS fungal infections present largely depends on the pathological reaction elicited by the fungus in the host. This interaction between the organism and the host is a complex one and depends on the virulence of the organism, the antigen makeup of the species and the immune status of the host. The host is frequently, although not always, immunocompromised. ${ }^{[7]}$ Predisposing factors are helpful in defining host defense. Disorders of phagocytic function predispose patients to the development of CNS aspergillosis, mucormycosis and candidiasis. Impairment of cell-mediated immunity predisposes patients to CNS cryptococcal, histoplasmal, coccidioidal and blastomycotic infections. Impairment of granulocyte function predisposes to CNS infection with Candida spp., Aspergillus spp., and Zygomycetes spp ${ }^{[8]}$ However, fungal infections can occur in otherwise immunocompetent individuals. Most of the patients with CNS aspergillosis reported from the Indian subcontinent are otherwise immunocompetent. ${ }^{[5,9,10]}$

\section{Clinical Syndromes}

The clinical syndromes with which fungal infections of the CNS can present are protean [Table 1]. These clinical syndromes can occur either alone or in combination. Certain clinical syndromes are specific for certain fungi [Table 2]. The rhinocerebral form is the most common presenting syndrome with zygomycosis. ${ }^{[11]}$ Because of the contiguous spread of the infection from the adjacent paranasal sinuses and orbit, skull-base syndromes are 


\begin{tabular}{|c|c|c|c|c|c|c|}
\hline Fungal infection & Meningitis & $\begin{array}{l}\text { Intracranial } \\
\text { mass lesions }\end{array}$ & $\begin{array}{l}\text { Skull-base } \\
\text { syndrome }\end{array}$ & $\begin{array}{l}\text { Rhinocerebral } \\
\text { form }\end{array}$ & $\begin{array}{c}\text { Stroke } \\
\text { syndrome }\end{array}$ & $\begin{array}{c}\text { Spinal } \\
\text { syndrome }\end{array}$ \\
\hline Aspergillosis & + & ++ & +++ & + & + & + \\
\hline Zygomycosis & \pm & ++ & - & +++ & + & - \\
\hline Cryptoccosis & +++ & + & - & - & + & + \\
\hline Pheohyphomycosis & + & +++ & - & - & - & - \\
\hline Candidiasis & + & - & - & - & + & - \\
\hline Penicilliosis & + & - & - & - & - & + \\
\hline
\end{tabular}

Table 2: Fungal infections of the CNS - skull-base syndromes

Orbital apex syndrome

Cavernous sinus syndrome

Proptosis with or without ocular palsy

Polyneuritis cranialis

Orbito-cranial syndromes

often the presenting clinical syndromes in patients with sinocranial aspergillosis. ${ }^{[5,12-14]}$

\section{Meningitis}

Meningitis and meningoencephalitis can be the presenting clinical syndrome with most of the yeasts (Cryptococcus spp. Blastomyces spp., Coccidioides spp., Paracoccidioides spp., Sporotrichum spp., Histoplasma spp. and Candida spp.) as they have access to the microcirculation from which they seed the subarachnoid space.

Meningitis is the predominant presenting clinical syndrome of cryptococcal infection..$^{[15-20]}$ Approximately $5-10 \%$ of HIV infected patients will develop cryptococcal meningitis as an AIDS-defining illness. ${ }^{[21]}$ In about $40 \%$ of patients, it may be the initial manifestation of HIV infection. ${ }^{[22]}$ Meningitis may be a manifestation of widely disseminated histoplasmosis or an isolated illness. Central nervous system involvement is clinically recognized in 5-10\% of cases of progressive disseminated histoplasmosis. ${ }^{[23]}$ Meningitis can be the presenting feature of primary phaeohyphomycosis of CNS (9\%), more often in an immunocompetent host. ${ }^{[2]}$ The most significant complication of Coccidioides infection is meningitis. ${ }^{[25]}$ Meningitis caused by Aspergillus spp. is very rare. ${ }^{[26,27]}$ Recently, a case series of aspergillus meningitis has been reported from Sri Lanka. It was suggested that it could be a post-tsunami effect. ${ }^{[28]}$ Bichili et al. ${ }^{[29]}$ reported a healthy subject with meningitis and granulomatous following zygomycetes infection.

Fungal meningitis tends to be a subacute or chronic process, however, it may be just as lethal as bacterial meningitis if untreated..$^{[30,31]}$ Fungi that produce a meningoencephalitis usually begin in the meninges as a meningitis and reach the brain by penetrating the brain's Virchow Robin spaces adjacent to the meninges. ${ }^{[32]}$ Meningoencephalitis is associated with altered mental status and seizures. Fungi can also produce meningeal vasculitis with vessel thrombosis and localized brain infarctions. ${ }^{[33]}$ Zygomycetes spp. and Aspergillus spp. are highly angioinvasive causing an arteritis or phlebitis that may result in vessel thrombosis or rarely rupture of the vessel wall with an accompanying cerebral or subarachnoid hemorrhage. ${ }^{[5,9,11]}$ The clinical manifestations may include focal neurological deficits and seizures.

Hydrocephalus and elevated intracranial pressure (ICP) are complications of chronic fungal meningitis. Elevated intracranial pressure (ICP) is reported in excess of $50 \%$ of HIV-1 infected patients with cryptococcal meningitis without accompanying hydropcephalus or cerebral edema. ${ }^{[17]}$ Importantly, clinical signs of raised intracranial pressure were absent even in those patients with highest opening pressures. ${ }^{[34]}$

\section{Intracranial mass lesions}

Histologically, the parenchymal mass lesions with fungal infections can be either an abscess or a granuloma. Abscess formation is common with certain fungi, Phaeohypomycosis spp. ${ }^{[5,9,24,35]}$ Zygomycetes spp. ${ }^{[5,11,36]}$ Candida spp. ${ }^{[5]}$ and rarely with Aspergillus spp..$^{[9]}$

Intracranial both intra- and extraparenchymal aspergillus granulomas are more frontal and temporal in location and rarely parietal, either with a focus in the paranasal sinuses or with no obvious sources. ${ }^{[5,9,10,14,37-44]}$

Patients with mass lesions present with focal deficits and raised intracranial pressure. Increased intracranial pressure can result from the mass effect of the lesion and/or surrounding cerebral edema. The focal deficits depend on the location of the lesion. ${ }^{[45]}$

\section{Skull-base syndromes}

Cranial and intracranial extension is frequent in patients with invasive type of Aspergillus sinusitis..$^{[5,10,12,13,46]}$ Basifrontal and basitemporal aspergillus granulomas in otherwise immunocompetent individuals have largely been reported from countries with tropical

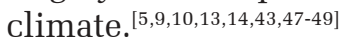

Patients with sinocranial aspergillosis may present with skull-base clinical syndromes [Table 3]..$^{[5,9,10,12-14]}$ Of the 21 patients with CNS aspergillosis studied by Murthy et al., ${ }^{[14]} 13$ presented with skull-base syndromes: cavernous sinus syndrome in five, orbital apex syndrome in three, proptosis with associated limitation of ocular movements in two and cranial neuropathy with or 
Table 3: Diagnosis of fungal infections of the CNS - red flags

Immunocompromised host and diabetes mellitus

HIV infection

Transplant patient

Prosthetic valves

Paranasal sinus infection

without meningeal signs in three. Of the 89 patients with CNS aspergillosis reported by Sundaram et al., ${ }^{[5]}$ 64 patients presented with skull-base syndromes: sinocranial in 47 , sino-orbito-cranial in nine and sinoorbital in eight.

\section{Rhinocerebral syndrome}

The rhinocerebral form is the most frequent presenting clinical syndrome in zygomycosis. ${ }^{[9,10,11,36]}$ Of the 56 patients with cerebral zygomycosis reported from two tertiary care centers in south India, ${ }^{[11]} 44$ (79\%) patients presented with rhinocerebral syndrome. Of the 178 patients with invasive zygomycosis studied in a tertiary care center in north India, $54.5 \%$ of patients presented with rhino-orbito-cerebral form. ${ }^{[50]}$ The clinical manifestations of the rhinocerebral form start as sinusitis, rapidly progressing to involve neighboring tissues like the orbit, eye and optic nerve and extend to the brain. Facial edema, pain, necrosis, loss of vision, black discharge along the nasal cavity angle of the eye and proptosis are usual features. As angio-invasion is very frequent, occlusion of the sphenopalatine artery and central retinal artery can occur, mostly effecting blindness. ${ }^{[11,36]}$

\section{Stroke syndromes}

Fungal infections known to cause cerebrovascular involvement include Aspergillosis, Candidiasis, Zygomycosis, Coccidiodomycosis, Cryptococcosis and Histoplasmosis. Vascular involvement is usually associated with large vessel vasculitis by invasion or embolization. [51]

Cerebral vasculitis due to fungal infections producing thrombosis and large infarcts is extremely uncommon. ${ }^{[2-55]}$ Very rarely, fungal infections of the CNS with vasculitis can present with subarachnoid hemorrhage. ${ }^{[56-58]}$ Sometimes both the pathological features can be the presenting features . Endo and colleagues ${ }^{[59]}$ described a case of fatal subarachnoid hemorrhage, with brainstem and cerebellar infarction, caused by Aspergillus infection after cerebral aneurysm surgery. Extremely rarely intracerebral hemorrhage can be the complication of fungal infections of the CNS. Adunsky and colleagues ${ }^{[60]}$ described an elderly patient with Aspergillus flavus meningitis and pontine hemorrhage.

Cardioembolic stroke can be the presenting feature of fungal endocarditis. Fungal endocarditis accounted for $1.3-6 \%$ of infective edocarditis. ${ }^{[61,62]}$ Candida is the most common causative organism of fungal endocarditis in both normal and immunocompromised hosts. ${ }^{[63]}$ Aspergillus is the second most common cause. ${ }^{[63,64]}$

Subarachnoid hemorrhage secondary to fungal mycotic intracranial aneurysm is an extremely rare complication. Intracranial aneurysms of fungal etiology are extremely rare and often the diagnosis is established at autopsy. Fungal mycotic intracranial aneurysms are usually found in the setting of disseminated hematogenous infection and fungal endocarditis. ${ }^{[65-74]}$ Rarely, they can occur following surgery ${ }^{[75]}$ and rarely from contiguous spread from the paranasal sinuses. ${ }^{[76]}$ In the first two settings the host is immunocompromised and in the latter settings the host is otherwise immunocompetent. The majority of intracranial fungal mycotic aneurysms are in the proximal portion of the major arteries at the base of the brain $^{[65-76]}$ and have been described with Aspergillus spp., Candida spp. and Zygomycetes spp. infections. Fungal mycotic aneurismal subarachnoid hemorrhage is often associated with very poor outcomes.

\section{Spinal syndromes}

Central nervous system fungal infections can rarely present as myelopathy and myeloradiculopathy. Infectious processes giving rise to spinal cord syndromes range from intramedullary granuloma or abscess, epidural abscess to focal spinal meningitis to frank fungal myelitis. Spinal cord involvement has been reported very rarely with aspergillosis..$^{[77-79]}$ It may be due to aspergilloma ${ }^{[78,79]}$ or epidural abscess. ${ }^{[80]}$ Upper thoracic level of spinal cord is most commonly affected, caused by contiguous spread from lung. ${ }^{[79-81]} \mathrm{Koh}$ et al. ${ }^{[82]}$ reported three children with myelopathy resulting from invasive aspergillosis. Spinal arachnoiditis has been described with aspergillosis and Cryptococcus neoformans. ${ }^{[83]}$ reported spinal intramedullary abscess caused by Candida albicans. ${ }^{[84]}$

Fungal infections of the CNS are being increasingly diagnosed both in immunocompromised and immunocompetent individuals. The clinical syndromes with which fungal infections of the CNS can present are protean and can involve most part of the neuroaxis. Certain clinical syndromes are specific with certain fungi. The rhinocerebral form is the most common presenting syndrome with zygomycosis and skull-base syndromes are often the presenting clinical syndromes in patients with sinocranial aspergillosis. Subacute and chronic meningitis in patients with HIV infection is more likely to be due to cryptococcal infection. Early recognition of the clinical syndromes in an appropriate clinical setting [Table 3] is the first step towards achieving total cure in some of these infections.

\section{References}

1. Baddley JW, Stroud TP, Salzman D, Pappas PG. Invasive mold infections in a allogeneic bone marrow transplantation recipients. Clin 
Infect Dis 2001;32:1319-24.

2. Clark TA, Hajjeh RA. Recent trends in the epidemiology of invasive mycoses. Curr Opin Infect Dis 2002;15:569-74.

3. Marr KA, Carter RA, Crippa F, Wald A, Corey L. Epidemiology and outcome of mold infections in hematopoietic stem cell transplant recipient. Clin Infect Dis 2002;34:909-17.

4. Banerjee U, Datta K, Majumdar T, Gupta K. Cryptococeosis in India: The awakening of a giant? Med Mycol 2001;39:51-67.

5. Sundaram C, Umabala P, Laxmi V, Purohit AK, Prasad VS, Panigrahi $\mathrm{M}$, et al. Histopathology of fungal infections of central nervous system: A seventeen years experience from south India. Histopathology 2006;49:396-405.

6. Nguyen MH, Yu VL. Meningitis caused by Candi da species: An emerging: problem in neurosurgical patients. Clin Infect Dis 1995;21:323-7.

7. Rees JR, Pinner RW, Hajjeh RA, Brandt ME, Reingold AL. The epidemiological features of invasive mycotic infections in the San Francisco Bay area, 1992-1993: Results of a population-based laboratory active surveillance. Clin Infect Dis 1998;27:1138-47.

8. Levitz SM. Overview of host defenses in fungal infections. Clin Infect Dis 1992;14:S37-42.

9. Santosh V, Yasha TC, Khanna N. Fungal infections of the nervous system - a pathological study. Neurol Infect Epidemiol 1996;1:69-79.

10. Sharma BS, Khosla VK, Kak VK, Banerjee AK, Vasishtha RK, Prasad KS, et al. Intracranial fungal granuloma. Surg Neurol 1997;47:48997.

11. Sundaram C, Mhadevan A, Laxmi V, Yasha TC, Santosh V, Murthy JM, et al. Cerebral zygomyeosis. Myeoses 2005;48:396-407.

12. Hedges TR, Leung LS. Paraseller and orbital apex syndrome caused by aspergillosis. Neurology 1976;26:117-20.

13. Naim-Ur-Rahman, Jamjoom A, al-Hedaithy SS, Jamjoom ZA, alSohaibani MO, Aziz SA. Cranial and intracranial aspergillosis of sinonasal origin. Report of nine cases. Acta Neurochir (Wein) 1996;138:94450 .

14. Murthy JM, Sundaram C, Prasad VS, Purohit AK, Rammurti S, Laxmi V. Sinocranial aspergillosis: A form of central nervous system aspergillosis in south India. Mycoses 2001;44:141-5.

15. Khanna N, Chandramuki A, Desai A, Ravi V. Cryptococeal infection of the central nervous system: An analysis of predisposing factors, laboratory findings and outcome in patients from South India with special reference to HIV infection. J Med Microbiol 1996;45:376-9.

16. Lanjewar DN, Jain PP, Shetty CR. Profile of central nervous system pathology in patients with AIDS: An autopsy study from India. AIDS 1998;12:309-13.

17. Saag MS, Graybill RJ, Larsen RA, Pappas PG, Perfect JR, Powderly WG, et al. Practical guidelines in the management of cryptococcal disease. Clin Infect Dis 2000;30:710-8.

18. Satishchandra P, Nalini A, Gourie-Devi M, Khanna N, Santosh V, Ravi $\mathrm{V}$, et al. Profile of neurological disorders associated with HIV/AIDS from Bangalore, South India (1986-1996). Indian J Med Res 2000;111:1423.

19. Sharma SK, Kadhiran T, Banga A, Goyal T, Bhatia I, Saha PK. Spectrum of clinical disease in a series of 135 hospitalized HIV-infected patients from North India. BMC Infect Dis 2004;4:52-60.

20. Shankar SK, Mhahdevan A, Satishchandra P, Kumar RU, Yasha TC, Santosh V, et al. Neuropathology of HIV;AIDS with an overview of the India scene. Indian J Med Res 2005;121:468-88.

21. Fessler RD, Sobel J, Guyot L, Crane L, Vazquez J, Szuba MJ, et al. Management of elevated intracranial pressure in patients with cryptococcal meningitis. J Acquir Immune Defic Syndr Hum Retrovirol $1998 ; 17: 137-42$

22. Wright D, Schneider A, Berger JR. Central nervous system opportunistic infections. Neuroimaging Clin North Am 1997;7:513-25.

23. Pancharoen C, Chindamporn A, Thisyakorn U. Childhood cryptococeosis: An increasing problem in the era of AIDS. J Med Assoc Thai 2001;84: S86-90.

24. Revankar SG, Sutton DA, Rinaldi MG. Primary central nervous system phaeohyphomycosis: A review of 110 cases. Clin Infect Dis 2004;38:20616.

25. Crum NF, Lederman ER, Stafford CM, Parrish JS, Wallace MR. Coccidioidomycosis: A descriptive survey of a reemerging disease.
Clinical characteristies and current controversies. Medicine (Baltimore) 2004;83:149-75.

26. Verweij PE, Brinkman K, Kremer HP, Kullberg BJ, Meis JF. Aspergillus meningitis: Diagnosis by non-culture-based microbiological methods and management. J Clin Microbiol 1999;37:1186-9.

27. Moling O, Lass-Floerl C, Verweij PE, Porte M, Boiron P, Prugger M, et al. Case Reports. Chronic and acute Aspergillus meningitis. Mycoses 2002;45:504-11.

28. Gunaratne PS, Wijeyaratne CN, Seneviratne HR. Aspergillus meningitis in Sri Lanka--a post-tsunami effect? N Engl J Med 2007;356:754-6.

29. Bichili LS, Abhyankar SC, Hase NK. Chronic mucormycosis manifesting as hydrocephalus. J Neurol Neurosurg Psychiatry 1985;48:1188.

30. Bouza E, Dreyer JS, Hewitt WL, Meyer RD. Coccidioidal Meningitis. An analysis of thirty-one cases and review of the literature. Medicine (Baltimore) 1981;60:139-72.

31. Prasad KN, Agarwal J, Nag VL, Verma AK, Dixit AK, Ayyagari A. Cryptococcal infection in patients with clinically diagnosed meningitis in a tertiary care center. Neurol India 2003;51:364-6.

32. Miszkiel KA, Hall-Craggs MA, Miller RG, Kendall BE, Wilkinson ID, Paley MN, et al. The spectrum of MRI findings in CNS cryptococeosis in AIDS. Clin Radiol 1996;51:842-50.

33. Mischel PS, Vinters HV. Coccidioidomycosis of the central nervous system: Neuropathological and vasculopathic manifestation and clinical correlates. Clin Infect Dis 1995;20:400-5.

34. Graybill JR, Sobel J, Saag M, van Der Horst C, Powderly W, Cloud G, et al. Diagnosis and management of increased intracranial pressure in patients with AIDS and cryptococcal meningitis. The NIAID Mycoses Study Group and AIDS Cooperative Treatment Groups. Clin Infect Dis $2000 ; 30: 47-54$

35. Gupta SK, Manjunath-Prasad KS, Sharma BS, Khosla VK, Kak VK, Minz M, et al. Brain abscess in renal transplant recipients: Report of three cases. Surg Neurol 1997;48:284-7.

36. Rangel-Guerra RA, Martinez HR, Saenz C, Bosques-Padilla F, EstradaBellmann I. Rhinocerebral and systemic mucormycosis: Clinical experience with 36 cases. J Neurol Sci 1996;143:19-30.

37. Linares G, McGarry PA, Baker RD. Solid solitary aspergillotic granuloma of the brain. Report of a case due to Aspergillus candidus and review of the literature. Neurology 1971;21:177-84.

38. Deshpande DH, Desai AP, Dastur HM. Aspergillosis of the central nervous system. A clinical and mycopathological study of 9 cases. Neurol India $1975 ; 23: 167-75$.

39. Whelan MA, Stern J, deNapoli RA. The computed tomographic spectrum of intracranial mycosis: Correlation with histopathology. Radiology 1981;141:703-7.

40. Dismukes WE, Stamm AM, Graybill JR, Craven PC, Stevens DA, Stiller RL, et al. Treatment of systemic mycoses with ketoconazole: Emphasis on toxicity and clinical response in 52 patients. National Institute of Allergy and Infectious Diseases collaborative antifungal study. Ann Intern Med 1983;98:13-20.

41. Young RF, Gade G, Grinnell V. Surgical treatment for fungal infections in the central nervous system. J Neurosurg 1985;63:371-81.

42. Fardoun R, Rao NK, Miskeen AK. Cerebral aspergilloma. Review of the literature apropos of a case. Neurochirurgie 1990;36:45-51.

43. Mohandas S, Ahuja GK, Sood VP, Virmani V. Aspergillosis of the central nervous system. J Neurol Sci 1978;38:229-33.

44. Nadkarni T, Goel A. Aspergilloma of the brain: An overview. J Postgrad Med 2005;51:S37-41.

45. Dubey A, Patwardhan RV, Sampth S, Santosh V, Kolluri S, Nanda A. Intracranial fungal granuloma: Analysis of 40 patients and review of the literature. Surg Neurol 2005;63:254-60.

46. Washburn RG, Kennedy DW, Begley MG, Henderson DK, Bennett JE. Chronic fungal sinusitis in apparently normal hosts. Medicine (Baltimore) 1988;67:231-47.

47. Kak VK, Banerjee AK, Radotra BD. Cerebral aspergillosis: Distinet clinicopathological pattern in 62 cases. Neurol India 1989;37:239.

48. Bahadur S, Kacker KK, D'Souza B, Chopra P. Paranasal fungal aspergillosis. J Laryngol Otol 1983;97:863-67.

49. Hazarika P, Ravikumar V, Nayak RG, Rao PS, Shivananda PG. Rhinocerebral mycosis. Ear Nose Throat J 1984;63:464-8.

50. Chakrabarti A, Das A, Mandal J, Shivaprakash MR, George VK, 
Tarai $\mathrm{B}$, et al. The rising trend of invasive zygomycosis in patiens with uncontrolled diabetes mellitus. Med Mycol 2006;44:335-42.

51. Somer T, Finegold SM. Vasculitides associated with infections, immunization and antimicrobial drugs. Clin Infect Dis 1993;20:101046 .

52. Kalita J, Bansal R, Ayagiri A, Misra UK. Midbrain infarction: A rare presentation of cryptococcal meningitis. Clin Neurol Neurosurg 1999;101:23-5.

53. Calli C, Savas R, Parildar M, Pekindil G, Alper H, Yunten N. Isolated pontine infarction due to rhinocerebral mucormycosis. Neuroradiology 1999;41:179-81

54. Goel D, Kalita J, Misra UK. Basilar artery occlusion in Cryptococcal meningitis. Neurol India 1999;47:245-6.

55. Murthy JM, Sundaram C, Prasad VS, Purohit AK, Rammurti S, Laxmi V. Aspergillosis of central nervous system: A study of 21 patients seen in a university hospital in south India. J Assoc Physicians India $2000 ; 48: 677-81$.

56. McKee EE. Mycotic infection of the brain with arteritis and subarachanoid hemorrhage: Report of case. Am J Clin Pathol 1950;20:3814.

57. Corvisier N, Gray F, Gherardi R, Lebras F, Blane CM, Nguyen JP, et al. Aspergillosis of ethmoid sinus and optic nerve, with arteritis and rupture of the internal carotid artery. Surg Neurol 1987;28:311-5.

58. Lau AH, Takeshita M, Ishii N. Mycotic (Aspergillus) arteritis resulting in fatal subarachnoid hemorrhage: A case report. Angiology 1991;42:2515 .

59. Endo T, Tominaga T, Konno H, Yoshimato T. Fatal subarachnoid hemorrhage, with brainstem and cerebellar infarction, caused by Aspergillus infection after cerebral aneurysm surgery: Case report Neurosurgery 2002;50:1147-51.

60. Adunsky A, Rubinstein E, Goldsmith A. Aspergillus flavus meningitis and pontine hemorrhage in an older patient. J Am Geriatr Soc 1996;44:739-40.

61. Bayer A, Scheld M. Endocarditis and intravascular infections. In: Mandell GL, Bennett JE, Dolin R, editors. Mandell Douglas and Bennett's principles and practice of infectious diseases. Churchill Livingstone: Philadelphia, PA; 2000. p. 857-902.

62. Karchmer AM. Infection on prosthetic valves and intravascular devices. In: Mandell GL, Bennett JE, Dolin R, editors. Mandell Douglas and Bennett's principles and practice of infectious diseases. Churchill Livingstone: Philadelphia, PA; 2000. p. 903-17.

63. Pierrotti LC, Baddour L. Fungal endocarditis, 1995-2000. Chest 2002;122:302-10.

64. Challa S, Prayaga AK, Vemu L, Sadasivan J, Jagarlapudi MK, Digumarti R, et al. Fungal endocarditis: An autopsy study. Asian Cardiovase Thorac Ann 2004;12:95-8.

65. Horten BC, Abbort GF, Porro RS. Fungal aneurysms of intracranial vessels. Arch Neurol 1976;33:577-9.

66. Iihara K, Makita Y, Nabeshima S, Tei T, Keyaki A, Nioka H. Aspergillosis of the central nervous system causing subarachnoid hemorrhage from mycotic aneurysm of the basilar artery--case report. Neurol Med Chir 1990;30:618-23.

67. Piotrowski WP, Pilz P, Chuang IH. Subarchnoid hemorrhage caused by a fungal aneurysm of the verebral artery as a complication of intracranial aneurysm clipping: Case report. J Neurosurg 1990;73:962-4.

68. Chou SM, Chong YY, Kinkel R. A proposed pathogenetic process in the formation of Aspergillus mycotic aneurysm in the central nervous system. Ann Acad Med Singapore 1993;22:518-25.

69. Radhakrishnana VV, saraswathy A, Rout D, Mohan PK. Mycotic aneurysms of the intracranial vessels. Indian J Med Res 1994;100:22831.

70. Kurino M, Kuratsu J, Yamaguchi T, Ushio Y. Mycotic aneurysm accompanied by aspergillotic granuloma: A case report. Surg Neurol $1994 ; 42: 160-4$

71. Suzuki K, Iwabuchi N, Kuramochi S, Nakanoma J, Suzuki Y, Serizawa $\mathrm{H}$, et al. Aspergillus aneurysm of the middle cerebral artery causing a fatal subarchnoid hemorrhage. Intern Med 1995;34:550-3.

72. Takeda S, Wakabayashi K, Yamazaki K, Miyakawa T, Arai H Intracranial fungal aneurysm caused by Cadida endocarditis. Clin Neuropathol 1998;17:199-203.

73. Watson JC, Myseros JS, Bullock MR. True fungal mycotic aneurysm of the basilar artery: A clinical and surgical dilemma. Cerebrovase Dis $1999 ; 9: 50-3$

74. Ho CL, Deruytter MJ. CNS aspergillosis with mycotic aneurysm, cerebral granuloma and infarction. Acta Neurochir (Wien) 2004;146:851-6.

75. Takeshita M, Izawa M, Kubo O, Tanikawa T, Onda H, Wanifuchi H, et al. Aspergillotic aneurysm formation of cerebral artery following neurosurgical operation. Surg Neurol 1992;38:146-51.

76. Hurst RW, Judkins A, Bolger W, Chu A, Loevner LA. Mycotic aneurysm and cerebral infarction resulting from fungal sinusitis: Imaging and pathologic correlation. AJNR Am J Neuroradiol 2001;22:858-63.

77. Seres JL, Ono H, Benner EJ. Aspergillosis presenting as spinal cord compression. J Neurosurg 1972;36:221-4.

78. Polatty RC, Cooper KR, Kerkering TM. Spinal cord compression due to an aspergilloma. South Med J 1984;77:645-8.

79. Sheth NK, Varkey B, Wagner DK. Spinal cord aspergillus invasion - complication of an aspergilloma. Am J Clin Pathol 1985;84:763-9.

80. Wagner DK, Varkey B, Sheth NK, DaMert GJ. Epidural abscess, vertebral destruction and paraplegia caused by extending infection from an aspergilloma. Am J Med 1985;78:518-22.

81. Nakazato I, Kamada Y, Taira T, Iwamasa T. Massive spinal cord necrosis associated with adult T-cell leukaemia caused by Aspergillus. Virchows Arch A Pathol Anat Histopathol 1993;423:397-400.

82. Koh S, Ross LA, Gilles FH, Nelson MD Jr, Mitchell WG. Myelopathy resulting from invasive aspergillosis. Pediatr Neurol 1998;19:135-8.

83. Woodall WC $3^{\text {rd }}$, Bertorini TE, Bakhtian BJ, Gelfand MS. Spinal arachnoiditis with Cryptococcus neoformans in a nonimmunocompromized child. Pediatr Neurol 1990;6:206-8.

84. Lindner A, Becker G, Warmuth-Metz M, Schalke BC, Bogdahn U, Toyka KV. Magnetic resonance image findings of spinal intramedullary abscess caused by Candida albicans: Case report. Neurosurgery 1995;36:4112.

Accepted on 30-08-2007

Source of Support: Nil, Conflict of Interest: None declared. 